\title{
Karakterisitik Kimia dan Total Koloni Bakteri Gelatin dari Beberapa Jenis Kulit Ternak
}

\section{Chemical Characteristics and Accounted Microbial Colony of Gelatin from Several Livestock Skins/Leather}

\author{
S. Melia, I. Juliyarsi, dan M. Hayatuddin \\ Fakultas Peternakan Universitas Andalas \\ Kampus Unand Limau Manis Padang, 25163 \\ e-mail : sri.melia75@gmail.com \\ (Diterima : 27 Juli 2014 , Disetujui : 16 September 2014)
}

\begin{abstract}
ABSTRAK
Penelitian ini bertujuan untuk mempelajari sifat kimia dan total koloni bakteri gelatin yang dihasilkan dari beberapa jenis kulit ternak. Bahan yang digunakan dalam penelitian ini adalah kulit sapi, kulit kerbau dan kulit kambing yang diperoleh dari rumah potong hewan di Padang. Metode yang digunakan adalah metode eksperimen Rancangan Acak Kelompok, 6 perlakuan dan 4 kelompok. Perlakuannya meliputi : (A). 100\% kulit sapi, (B). 100\% kulit kerbau, (C). 100\% kulit kambing, (D). 50\% kulit sapi : 50\% kulit kerbau, (E). 50\% kulit sapi : 50\% kulit kambing, (F). 50\% kulit kerbau : 50\% kulit kambing. Selanjutnya data yang diperoleh dianalisis menggunakan analisis stastistik dan uji lanjut dengan Duncan's Multiple Range Test (DMRT). Peubah yang diamati dalam penelitian ini adalah kadar protein, kadar lemak dan total koloni bakteri. Hasil penelitian menunjukkan bahwa gelatin yang dihasilkan dari beberapa jenis kulit ternak berpengaruh nyata $(\mathrm{p}<0,05)$ terhadap kadar protein, kadar lemak dan total koloni bakteri. Gelatin yang terbaik dari hasil penelitian adalah gelatin yang diperoleh dari kulit sapi $100 \%$, dengan kadar protein $31,47 \%$, kadar lemak $1,43 \%$ dan total koloni bakteri $8,34 \times 10^{5} \mathrm{CFU} / \mathrm{g}$.
\end{abstract}

Kata kunci : gelatin, kulit sapi, kulit kerbau, kulit kambing

\section{ABSTRACT}

A study was conducted to evaluate chemical charateristics and total microbial colony of gelatin produced from several livestock skins. The used materials in the research consisted of several skins; cattle, buffalo and goat purchased from abattoir. An experimental method with randomized block design used to collect primary data with 6 treatments and 4 replications. Then collected data were analyzed by DMRT at $95 \%$ of level of confidence $(P<0.05)$. Treatments made up of following categories: (A). 100\% cattle skin, (B). 100\% buffalo skin, (C). 100\% goat skin, (D). $50 \%$ cattle skin : 50\% buffalo skin, $(E)$. 50\% cattle skin : 50\% goat skin, $(F)$. $50 \%$ buffalo skin : $50 \%$ goat skin. The results showed that there was a significantly different effect $(P<0.05)$ on protein, fat and bacterial colonies account. Gelatin from $100 \%$ cattle skin showed the best quality containing $31.47 \%$ protein, $1.43 \%$ fat and $8.34 \times 10^{5}$ CFU/g bacterial colonies.

Keywords : gelatin, cattle skins, buffalo skins, goat skins

\section{PENDAHULUAN}

Gelatin adalah biopolimer dengan sifat fungsional penting yang dimanfaatkan secara luas pada makanan untuk memperbaiki elastisitas, konsistensi dan stabilitas. Tidak hanya diperoleh dari tulang dan kulit hewan tetapi juga berasal dari tulang dan kulit ikan. Gelatin merupakan protein yang dihasilkan dari denaturasi kolagen yang umumnya berasal dari protein hewani. Gelatin adalah produk yang dihasilkan dari ekstraksi dengan asam, basa atau proses enzimatik dari kolagen, yaitu bagian protein yang berasal dari kulit, tulang dan jaringan hewan lainnya (Tabata and Yoshito, 1998, Jhonston-Banks, 1990). Proses pengolahan gelatin dibagi ke dalam 2 metode 
yaitu proses asam dan proses basa. Gelatin yang diolah dengan proses basa disebut dengan gelatin tipe $\mathrm{A}$, sedangkan gelatin yang dengan proses asam disebut gelatin tipe $\mathrm{B}$ (Peng and Joe, 2005). Reaksi kimia dan modifikasi enzim dapat memperluas aplikasi gelatin di bidang makanan dan farmasi (Djagny, et al., 2001).

Saat ini, gelatin banyak dalam bentuk tepung, meskipun di Eropa masih ditemui dalam bentuk lembaran. Gelatin dengan proses ekstraksi asam, mempengaruhi sifat viskoelastisitas dan kekuatan gel. Asam yang digunakan adalah asam asetat, asam propionate dan asam sitrat (Gomez dan Montero, 2001). Kualitas gelatin tergantung pada sifat reologinya. Selain itu juga tergantung pada kelarutan, warna, aroma, rasa, serta kekuatan gel dan stabilitas panas (Yang and Wang, 2009).

Aplikasi gelatin dalam industri pangan sudah sangat luas, seperti es krim, keperluan medis dan farmasi serta industri fotografi (Amiza and Aishah, 2011). Gelatin merupakan hidrokoloid yang bersifat unik, dengan fungsi dan aplikasi yang luas. Sumber utama gelatin meliputi kulit babi, tulang dan kulit sapi (Karim and Bath, 2008; Paulien, 1999). Sumber gelatin yang paling besar yaitu berasal dari kulit babi (46\%), kulit sapi $(29,4 \%)$, tulang $(23,1 \%)$. Sedangkan gelatin yang bersumber dari ikan, produksinya kecil dari $1,5 \%$ pada tahu 2007 (Gomez-Guillen, 2009).

Sehubungan dengan hal di atas, diperlukan perbandingan sifat gelatin yang diolah dari beberapa jenis kulit ternak yang umum ada di Indonesia yaitu sapi, kerbau dan kambing. Tujuan penelitian ini adalah untuk meneliti karakteristik kimia dan total koloni dari gelatin yang berasal dari beberapa jenis kulit ternak yaitu kulit sapi, kulit kambing, kulit kerbau dan kombinasi ketiga kulit tersebut.

\section{METODE}

Kulit yang digunakan dalam penelitian adalah kulit sapi, kulit kerbau dan kulit kambing yang diperoleh dari Rumah Potong Hewan di Bandar Buat. Bahan kimia yang digunakan adalah kapur, aquades, dan $\mathrm{HCl}$ $1 \%$.

Penelitian ini menggunakan metode eksperimen dengan Rancangan Acak Kelompok (RAK), terdiri dari 6 perlakuan dan 4 kelompok, kelompok sebagai ulangan. (A). 100\% kulit sapi, (B). 100\% kulit kerbau, (C). 100\% kulit kambing, (D). 50\% kulit sapi : 50\% kulit kerbau, (E). 50\% kulit sapi : 50\% kulit kambing, (F). 50\% kulit kerbau : 50\% kulit kambing. Selanjutnya data yang diperoleh Dianalisis menggunakan analisis stastistik dan uji lanjut dengan Duncan's Multiple Range Test (DMRT). Peubah yang diamati dalam penelitian ini adalah kadar protein (Sudarmadji, Haryono dan Suhardi, 1997), kadar lemak (Sudarmadji, et al., 1997) dan total koloni bakteri (Harley and Presocott, 1993). Penelitian dilakukan di laboratorium Teknologi Hasil Ternak dan Laboratorium Kesehatan Ternak Fakultas Peternakan Universitas Andalas pada bulan Januari-April 2011 dan RPH Bandar Buat tempat mengambil kulit yang akan dijadikan materi penelitian.

\section{Ekstraksi Gelatin (Satria, 2008).}

Kulit ternak dibersihkan dari sisa daging, darah, dan kotoran yang menempel dan dikelompokkan sesuai perlakuan. Kulit ditimbang masing-masingnya 1500 g. Kulit direndam dalam air kapur selama 1 minggu dan dibolakbalik minimal 3 kali sehari. Selanjutnya dilakukan pembuangan bulu dan kulit dicuci dengan air mengalir hingga mendekati $\mathrm{pH} 7$. Kulit dipotong ukuran kecil dan direndam dalam larutan $\mathrm{HCl} 1 \%$ sebanyak $1500 \mathrm{ml}$ selama 6 jam. Setelah itu dilakukan ekstraksi bertahap : tahap 1 . Suhu $60^{\circ} \mathrm{C}$ selama 4 jam, tahap 2 . Suhu $70^{\circ} \mathrm{C}$ selama 4 jam dan tahap 3. Suhu $80^{\circ} \mathrm{C}$ selama 4 jam. Selanjutnya difiltrasi dan dipekatkan dengan cara pemanasan pada suhu $60^{\circ} \mathrm{C}$ selama 5 jam. Sehingga dihasilkan gelatin berbentuk pasta.

\section{HASIL DAN PEMBAHASAN}

\section{Kadar Protein}

Hasil pengukuran kadar protein gelatin dapat dilihat pada Tabel 1. 
Tabel 1. Kadar protein gelatin dari beberapa jenis kulit ternak

\begin{tabular}{lc}
\hline \multicolumn{1}{c}{ Perlakuan } & Protein $(\%)$ \\
\hline A ( Kulit sapi) & $31,47 \pm 1,63^{\mathrm{a}}$ \\
B (Kulit kerbau) & $26,29 \pm 2,68^{\mathrm{b}}$ \\
C (Kulit Kambing) & $23,16 \pm 1,34^{\mathrm{bc}}$ \\
D (50\% Kulit sapi : 50\% Kulit kerbau) & $27,97 \pm 1,48^{\mathrm{b}}$ \\
E (50\% Kulit sapi : 50\% Kulit kambing) & $26,97 \pm 2,17^{\mathrm{b}}$ \\
F (50\% Kulit kerbau : 50\% Kulit kambing) & $24,64 \pm 1,56^{\mathrm{b}}$ \\
\hline
\end{tabular}

Keterangan : Rataan dengan superskrip huruf yang berbeda menunjukkan pengaruh yang berbeda nyata $(\mathrm{P}<0,05)$

Kadar protein gelatin dari beberapa jenis kulit sapi berkisar antara 23,16\%-31,47\%. Hasil analisis statistik menunjukkan bahwa perlakuan memberikan pengaruh yang nyata $(\mathrm{P}<0,05)$ terhadap kadar protein gelatin. Berdasarkan uji lanjut DMRT, kadar protein perlakuan A (kulit sapi) nyata $(\mathrm{P}<0,05)$ lebih tinggi dibanding perlakuan $\mathrm{D}, \mathrm{B}, \mathrm{E}, \mathrm{F}$ dan $\mathrm{C}$. Hal ini disebabkan karena kadar kolagen pada kulit sapi lebih tinggi dibanding kulit lainnya. Sesuai dengan pendapat Arcos et al., (2002), kolagen pada kulit sapi adalah $43,75 \%$. Sedangkan menurut Sharpouse (1978), kolagen pada kulit kambing adalah $29 \%$. Gelatin merupakan polipeptida yang dihasilkan dari hidrolisis parsial kolagen yang berasal dari kulit hewan, jaringan dan tulang (Sarbon, et al., 2013)

Seperti yang tampak pada Tabel 2, kadar protein kulit sapi juga lebih tinggi dibanding kulit kerbau dan kulit kambing. Semakin tinggi protein yang terdapat pada kulit maka semakin tinggi kadar protein gelatin yang dihasilkan dari proses hidrolisis protein kolagen. Sedangkan pada kombinasi kulit ternak memberikan hasil yang berbeda tidak nyata $(P>0,05)$ terhadap kadar protein.

Kadar protein gelatin dari kulit sapi pada penelitian ini lebih rendah bila dibandingkan dengan hasil penelitian Sarbon, et al. (2013), yang melaporkan bahwa kadar protein dari ekstrak gelatin kulit sapi yaitu $81,75 \pm 0,50 \%$. Hal ini disebabkan karena ekstrak gelatin dari penelitian Sarbon et al. (2013), diproses dalam bentuk tepung gelatin dengan kadar air $9,68 \pm 0,06 \%$. Said, et al. (2011), menghasilkan gelatin dari kulit kambing dengan proses asam (asam asetat 4\%), memiliki kadar protein $90,74 \%$ dalam bentuk tepung gelatin.
Hamid (2011), protein dari berbagai jenis kulit ternak yaitu, kulit sapi $29,96 \%$, kulit kerbau $21,15 \%$ dan kulit kambing proteinnya 19,98\%.

\section{Kadar Lemak}

Hasil pengukuran kadar lemak gelatin dari beberapa jenis kulit ternak dapat dilihat pada Tabel 3. Kadar lemak gelatin berkisar antara $0,76 \%-1,82 \%$. Hasil analisis statistik menunjukkan bahwa perlakuan berpengaruh nyata $(\mathrm{P}<0,05)$ terhadap kadar lemak. Namun kadar lemak secara keseluruhan berbeda tidak nyata antara perlakuan A, B, C dengan D, E dan $F$, ini disebabkan karena dalam proses pembentukan gelatin, yang mengalami proses hidrolisis adalah protein, sehingga kadar lemak masing-masingnya tetap. Kadar lemak pada gelatin yang diperoleh dari beberapa jenis kulit pada semua perlakuan $(0,76 \%$ $1,82 \%$ ), lebih rendah bila dibandingkan dengan hasil penelitian, Amiza dan Aishah (2011), kadar lemak ekstrak gelatin dari kulit ikan cobia yaitu $2,62 \%$. Tetapi lebih tinggi bila dibandingkan dengan penelitian Said, et al. (2011), menghasilkan gelatin dari kulit kambing dengan proses asam (asam asetat 4\%), dengan kadar lemak 0,35\%.

\section{Total Koloni Bakteri}

Total koloni bakteri gelatin yang dihasilkan dari beberapa jenis kulit ternak dapat dilihat pada Tabel 4. Total koloni bakteri gelatin berkisar antara $7,82 \times 10^{5} \mathrm{CFU} / \mathrm{g}$ $25,44 \times 10^{5} \mathrm{CFU} / \mathrm{g}$. Hasil analisis statistik menunjukkan bahwa perlakuan berpengaruh nyata $(\mathrm{P}<0,05)$ terhadap total koloni bakteri gelatin. Tingginya total koloni bakteri pada perlakuan E, yaitu 37,33 x $10^{5} \mathrm{CFU} / \mathrm{g}$, disebabkan karena kadar air yang tinggi yang terdapat pada gelatin tersebut. 
Tabel 3. Kadar lemak gelatin dari beberapa jenis kulit ternak

\begin{tabular}{lc}
\hline \multicolumn{1}{c}{ Perlakuan } & Lemak (\%) \\
\hline A ( Kulit sapi) & $1,43 \pm 0,36^{\mathrm{a}}$ \\
B (Kulit kerbau) & $1,61 \pm 0,04^{\mathrm{a}}$ \\
C (Kulit Kambing) & $1,82 \pm 0,04^{\mathrm{a}}$ \\
D (50\% Kulit sapi : 50\% Kulit kerbau) & $0,76 \pm 0,50^{\mathrm{b}}$ \\
E (50\% Kulit sapi : 50\% Kulit kambing) & $1,05 \pm 0,31^{\mathrm{ab}}$ \\
F (50\% Kulit kerbau : 50\% Kulit kambing) & $1,34 \pm 0,50^{\mathrm{a}}$ \\
\hline
\end{tabular}

Keterangan : Rataan dengan superskrip huruf yang berbeda menunjukkan pengaruh yang berbeda nyata $(\mathrm{P}<0,05)$

Tabel 4. Total koloni bakteri gelatin dari beberapa jenis kulit ternak

\begin{tabular}{lc}
\hline \multicolumn{1}{c}{ Perlakuan } & Total Koloni Bakteri ( $\left.10^{5} \mathrm{CFU} / \mathrm{g}\right)$ \\
\hline A ( kulit sapi) & $8,34 \pm 1,88^{\mathrm{b}}$ \\
B (kulit kerbau) & $13,44 \pm 1,73^{\mathrm{b}}$ \\
C (kulit kambing) & $12,51 \pm 1,64^{\mathrm{b}}$ \\
D (50\% kulit sapi : 50\% kulit kerbau) & $7,82 \pm 1,52^{\mathrm{b}}$ \\
E (50\% kulit sapi : 50\% kulit kambing) & $37,33 \pm 1,53^{\mathrm{a}}$ \\
F (50\% kulit kerbau : 50\% kulit kambing) & $25,44 \pm 1,89^{\mathrm{ab}}$ \\
\hline Keterangan : Rataan dengan superskrip huruf yang berbeda menunjukkan pengaruh yang berbeda nyata $(\mathrm{P}<0,05)$
\end{tabular}

Sehingga air sebagai salah satu media untuk pertumbuhan mikroba, dimanfaatkan oleh bakteri untuk pertumbuhannya. Hal ini didukung oleh penelitian Hamid (2011), menyatakan bahwa kadar air pada campuran 50\% kulit sapi : $50 \%$ kulit kambing, menghasilkan kadar air tertinggi yaitu 66,84\%. Buckle, et al. (2007), menyatakan bahwa mikroba membutuhkan air untuk pertumbuhannya yang berperan dalam reaksi metabolik dalam sel. Selanjutnya menurut Sharpouse (1978), kadar air kulit kambing yaitu 64\%, sedangkan menurut Nadia (2005), kadar air kulit sapi berkisar $66,87 \%$.

\section{KESIMPULAN}

Dari penelitian ini dapat disimpulkan bahwa gelatin yang dihasilkan dari beberapa jenis kulit ternak berpengaruh nyata $(\mathrm{P}<0,05)$ terhadap kadar protein, kadar lemak dan total koloni bakteri. Gelatin yang terbaik dari hasil penelitian adalah gelatin yang diperoleh dari kulit sapi (Perlakuan A), dengan kadar protein $31,47 \%$, kadar lemak $1,43 \%$ dan total koloni bakteri $8,34 \times 10^{5} \mathrm{CFU} / \mathrm{g}$.

\section{DAFTAR PUSTAKA}

Arcos-Garcia, G., A. Totosaus, I. Guerro and M.L., Perez-Chabela. 2002. Physicochemical, sensory, functional and microbial characterisation of horse meat. R. Bras. Agrocencia, 8 : 43-46

Amiza, M.A and S. Aishah. 2011. Effect drying and freezing of cobia (rachycentron canadum) skin on its gelatin properties. International food $\mathrm{Re}$ search Journal, 18:159-166.

Buckle, K.A., R.A., Edwards, G.H., Fleet dan M.Wooton. 2007. Ilmu Pangan. Terjemahan Hari Purnomo dan Adiono. Universitas Indonesia.

Djagny, K.B, W. Zhang, and X. Shiying. 2001. Gelatin : A valuable for food and pharmaceutical Industry : Review. Critical Review in Food Science and Nutrition, 41 (6): 481-492

Gomez, M. C and P. Montero. 2001. Extraction gelatin from megrim (Lepidorhombus boscii) skins with several organis acids. J.of Food Science, 66 (2):213-216.

Gomez-Gullien, M.C. 2009. Antioxidant and functional properties of gelatin hydrolysates obtained from skin of sole and 
squid. Food Chemistry, 114(3) : 976983

Hamid, R. S. 2011. Evaluasi berbagai jenis kulit ternak terhadap sifat fisik gelatin. Skripsi Fakultas Peternakan Universitas Andalas, Padang.

Harley, J.P and L. M. 1993. Laboratory exercises in Microbiology. Second Edition. WCB Publishers, Oxford.

Jhonston-Banks, F.A. 1990. Gelatin. In P. Haris (Ed), food Gel (pp.233-289). London-elsivier applied Science Publisher.

Karim A.A, and Bath. R. 2008. Gelatin alternatives for the food industry : recent developments, challenges and prospects. Trends in Food Sience and Technology. 19 (12) : 644-656

Nadia. 2005. Nutrisi dan beberaoa criteria halal kerupuk kulit jangek. J.Matematika, Sains dan Teknologi, 6 (2) : 100-107

Paulien, K. 1999. Life without gelatin. Dairy Industry International. 64(4) : 25-26; ProQuest.

Peng, $\mathrm{Z}$ and M.R. Joe. 2005. Effect of alkaline and acid pretreatments on Alaska pollock skin gelatin extraction. J.of Food Science 70 (6) : 392-396.

Said, M.I., Likadja J.C., dan Hatta M., 2011. Pengaruh waktu dan konsentrasi bahan curing terhadap kualitas dan kuantitas gelatin kulit kambing yang diproduksi melalui proses asam. JITP, 1 (2) : 119-128

Sarbon, N.M., B. Farah, and K.H. Nazlim. 2013. Preparation and characterization of chicken skin gelatin as an alternative to mammalian gelatin. Food Hydrocolloids, 30 : 143-151

Satria, E. 2008. Pengaruh lama perendaman dalam asam khlorida $(\mathrm{HCl})$ terhadap kualitas gelatin dari kulit sapi. Skripsi Fakultas Peternakan Universitas Andalas, Padang.

Sharpous, J.H. 1978. Leather Technician's Handbook. Leather Producer Association. London.

Sudarmadji, S., B. Haryono, dan Suhardi. 1997. Analisa Bahan Makanan dan Pertanian. Edisi VI. Liberty Yogyakarta Bekerjasama dengan Pusat Antar Universitas Pangan dan Gizi Universitas Gadjah Mada, Yogyakarta.

Tabata, D and I. Yoshito. 1998. Protein release from gelatin matrices. Advanced Drug Delivery Reviews. 31(3) : 287-301. Elsevier.

Yang, $\mathrm{H}$ and Wang, Y. 2009. Effect of concentration on nanostructural images and physical properties of gelatin from channel catfish skins. Food Hydrocolloids, 23 : 577-584 